\title{
Pendampingan Literasi Digital Kampung KB RW 2 Kelurahan Gedawang Banyumanik Kota Semarang
}

\author{
Made Dwi Adnjani; Dian Marhaeni Kurdaningsih; Urip Mulyadi \\ Program Studi Ilmu Komunikasi, FBIK, Universitas Islam Sultan Agung Semarang \\ Email:made@unissula.ac.id,marhaeni@unissula.ac.id, oeripmulia@unissula.ac.id
}

\section{Article Info}

Submitted: 3 June 2020

Revised: 22 July 2020

Accepted: 30 December 2020

Published: 21 April 2021

Keywords: Literacy, Digital, $K B$ Village
Kata kunci: Literasi, Digital, Kampung KB

\section{Abstract}

There are three categories of audiences that are vulnerable to the bad influence of the internet, children, adolescents and mothers. In children, this influence mainly lies in brain development, emotional, social, and cognitive abilities. The intensity will affect the perception of what they watch. One of the efforts to overcome these negative effects is digital literacy. Based on the information obtained, in Gedawang village, RW 2 as a $K B$ village, to be precise, has not received information about digital literacy, so this activity needs to be carried out. This activity uses lecture, discussion and simulation methods. In general, this activity raises awareness of the importance of the role of parents in assisting children in utilizing digital media. This is where parents need to understand the main values of the digital world that drives our lives today. There are three important values: creativity, collaboration and critical thinking. Participants through this activity will not only increase their knowledge but also realize the need to understand good information ethics. The output of this service is in addition to documentation of activities, as well as publications in print and online media, including in the insight newspaper, suarabaru.id, rri.co.id. In addition, scientific articles published in community service journals are also made.

\footnotetext{
Abstrak

Terdapat tiga kategori khalayak yang rentan terhadap pengaruh buruk internet, yakni anak-anak, remaja, dan kaum ibu. Pada anak-anak, pengaruh itu terutama terletak pada perkembangan otak, emosi, sosial, dan kemapuan kognitif. Intensitas akan memengaruhi persepsi dengan apa yang mereka tonton. Salah satu upaya menanggulangi dampak buruk tersebut adalah dengan literasi digital. Berdasarkan informasi yang diperoleh, di Kelurahan Gedawang tepatnya wilayah RW 2 sebagai Kampung KB belum mendapatkan informasi tentang literasi digital, sehingga kegiatan ini perlu dilakukan. Kegiatan ini menggunakan metode ceramah, diskusi, dan simulasi. Secara umum kegiatan ini membangkitkan kesadaran betapa pentingnya peran
} 
orang tua dalam mendampingi anak-anak dalam pemanfaatan media digital. Disinilah para orang tua perlu memahami nilai utama dunia digital yang menyetir kehidupan kita saat ini. Ada tiga nilai penting: kreativitas, kolaborasi, dan berpikir kritis. Para peserta melalui kegiatan ini selain pengetahuannya akan semakin meningkat juga semakin menyadari perlunya memahami etika informasi yang baik. Luaran dari kegiatan pengabdian ini selain dokumentasi kegiatan, juga publikasi di media cetak dan online, diantaranya di koran wawasan, suarabaru.id, rri.co.id. Di samping itu juga pembuatan artikel ilmiah yang dimuat di jurnal pengabdian masyarakat.

\section{PENDAHULUAN}

Penyebaran konten negatif masih marak di dunia maya, maka dari itu diperlukan adanya gerakan literasi digital. Kemampuan untuk memahami literasi digital bertujuan agar mampu membedakan mana informasi yang benar dan tidak. Hasil riset tahunan Indonesia Digital Mums (IDM) 2018 mengenai tren perilaku online lebih dari 1.000 ibu-ibu digital masa kini terungkap bahwa terjadi peningkatan penggunaan internet sebanyak 48,7\% Dalam survei juga terungkap enam temuan penting. Temuan pertama, konsumsi internet meningkat secara signifikan.

Temuan kedua, Instagram menjadi platform media sosial yang paling banyak digunakan. Instagram telah mengambil alih Facebook sebagai platform media sosial yang paling banyak digunakan dengan lebih dari 98,5\% ibu digital Indonesia memiliki setidaknya satu akun Instagram. Temuan ketiga, smartphone sebagai pilihan utama menjelajahi internet. Keempat, konsumsi video dan media telah beralih ke digital. Kelima, ibu berbelanja online 2-3 kali sebulan dengan didominasi produk anak-anak. Terakhir atau keenam, ibu digital masa kini turut menikmati pertumbuhan dompet digital. (Okezone.com, 2018).

Istilah literasi media baru sering disamakan dengan digital literacy atau literasi digital karena media baru dapat dikatakan identik dengan media digital, meskipun tidak selalu berarti Internet. Menurut Media Awareness Network definisi literasi digital yang sudah cukup dikenal adalah: keterampilan dan pengetahuan yang diperlukan untuk menggunakan berbagai perangkat lunak aplikasi media digital, perangkat keras seperti komputer, telepon seluler, dan teknologi internet; kemampuan untuk secara kritis memahami konten media digital dan aplikasinya; dan pengetahuan dan kapasitas untuk menciptakanisi media dengan teknologi digital (Novianti \& fatonah, 2018).

Literasi digital menurut Kamus Besar Bahasa Indonesia adalah pengetahuan dan kecakapan untuk menggunakan media digital, alat-alat komunikasi atau jaringan dalam menemukan, mengevaluasi, menggunakan media digital, alat-alat komunikasi atau jaringan dalam menemukan, mengevaluasi, menggunakan, membuat informasi dan memanfaatkannya secara sehat, bijak, cerdas, cermat, tepat, dan patuh hukum dalam rangka membina komunikasi dan interaksi dalam kehidupan sehari-hari. Ada juga yang mendefinisikan literasi digital sebagai kemampuan menggunakan teknologi informasi untuk mengkomunikasikan konten atau informasi dengan kecakapan kognitif dan teknikal.

Literasi Digital menurut Potter (2004, 2014) memiliki tiga elemen penting, yang pertama yaitu kompetensi atau kecakapan yang harus dimiliki oleh individu ketika mengakses media baru. Elemen kedua adalah lokus personal yaitu individu yang berinteraksi dengan individu lain, dalam hal ini konsekuensi sosial dari literasi digital menjadi penting. Literasi digital berguna ketika individu memerlukannya. Dalam kondisi pandemi Covid-19 literasi tentang komunikasi bencana menjadi berguna untuk masyarakat yang tidak tahu tentang apa yang harus dilakukan dalam kondisi panik dan krisis seperti sekarang ini. Dengan demikian lokus personal juga memiliki konsekuensi sosial karena menurut Potter tidak hanya berkaitan dengan diri individu tetapi juga dengan individu ketika 
berinteraksi dengan individu lain dan komunitas. Ketika berhadapan dengan media baru, individu dapat memiliki tiga posisi, yaitu indvidu yang termediasi, individu yang virtual, dan individu yang berjaringan ini artinya individu yang berbagi dan berkolaborasi dengan individu lain melalui media baru (Bolter \& Grusin, 1999). Elemen ketiga menurut Porter yang tidak kalah pentingnya adalah struktur pengetahuan karena literasi digital pada akhirnya akan menjadikan individu memiliki pengetahuan yang baik mengenai informasi dan dunia sosial yang dijalaninya. Apabila diuraikan lebih jauh di dalam definisi tersebut terkandung tiga kata kerja yang merupakan karakteristik dari literasi digital, yaitu: use - understand - create. Artinya, literasi media mencakup kemampuan untuk menggunakan, memahami, dan memproduksi media digital.

Wirodono dalam novianti (2018) mengemukakan tiga kategori khalayak yang rentan terhadap pengaruh buruk media, yakni anak-anak, remaja, dan kaum ibu. Pada anakanak, pengaruh itu terutama terletak pada perkembangan otak, emosi, sosial, dan kemapuan kognitif. Intensitas akan mempengaruhi persepsi dengan apa yang mereka tonton. Kekhawatiran tersebut misalnya dari pengaruh tayangan kekerasan pada anak-anak yang sering ditiru. Selain itu tayangan berbau seks dan mistis menjadi kekhawatiran para ibu-ibu. Pada remaja, tayangan sinetron dengan tema remaja cenderung mengeksploitasi kehidupan remaja dari satu sisi.

Keadaan ini menyebabkan remaja tidak bisa mempelajari realitas yang sesungguhnya. Bagi ibu-ibu pengaruh buruk televisi lebih pada membangun perilaku konsumtif. Mereka merupakan sasaran potensial iklan. Komoditas ini dikemas dalam bentuk tayangan sinetron, infotainment, tayangan kuliner, dan sebagainya Wirodono (dalam Novianti, 2018).

Pengabdian masyarakat ini dilakukan di wilayah Kelurahan Gedawang yang masuk kategori daerah pinggiran kota Semarang. Pengabdian ini dilakukan di RW 2 dan juga kampung KB di RW 2 tersebut. Sebagian masyarakat memiliki mata pencaharian sebagai karyawan perusahaan di garmen, roti, mie, dan sebagainya. Sebagiannya lagi adalah petani, mereka memiliki lahan yang terhampar di lereng pengunungan tepatnya di sebelah timur jalan tol Semarang-Bawen. Diantara mereka adalah ibu rumah tangga yang bekerja di rumah. Mereka memiliki industri rumahan seperti membuat kue, camilan, kerupuk, dan lauk pauk yang dikemas dan dijual di masyarakat sekitar.

Sebagai salah satu kampung KB di Kota Semarang, beragam aktivitas dilakukan sebagai agenda rutin yang dilakukan seperti pertemuan, arisan, dan kegiatan lain untuk meningkatkan pengatahuan dan keterampilan. Di samping itu, masyarakat di kampung KB tentu harus memiliki pemahaman terkait penggunaan gadget dan internet. Pemahaman penggunaan internet dan gadget yang sehat akan membuat mereka lebih bijak dalam bersosial-media dan melakukan aktivitas online. Karena dalam beberapa hal penggunaan media sosial yang kurang tepat akan memberikan dampak negatif.

Selain itu, akun media sosial adalah milik individual, namun tanpa pengaturan privasi yang memadai, akun media sosial dapat dikonsumsi oleh publik (orang-orang yang tidak pernah kita tambahkan sebagai teman). Selain itu, kebanyakan orang tua dan juga pemangku kepentingan (yang sebagian besar adalah orang tua) seringkali kurang berhatihati ketika memposting foto anak-anak pada akun sosial media mereka. Kebanyakan orang tua dan pemangku kepentingan lain kebanyakan tidak memiliki informasi mengenai COPPA (Children's Online Privacy Protection Act). COPPA menyatakan bahwa anak-anak di bawah usia 13 tahun adalah tanggung jawab orang tua mereka. Selain itu, COPPA memberikan wewenang pada orang tua memberikan persetujuan (consent) informasi tentang anak yang dapat dipublikasi pada situs online. Akibatnya, banyak di antara orang tua dan para pemangku kepentingan yang memberikan informasi mengenai anak di bawah usia 13 tahun di ranah maya (Endah dkk., 2017).

Tujuan kegiatan pengabdian yang dilakukan oleh tim pengabdian program studi ilmu komunikasi Fakultas Bahasa dan Ilmu Komunikasi Universitas Islam Sultan Agung (UNISSULA) ini adalah untuk melakukan sosialisasi penggunaan internet sehat dan membuat model literasi media digital bagi ibuibu rumah tangga yang ada di RW 2 kelurahan 
Gedawang, Kota Semarang. Literasi media digital ini dilakukan menggunakan bahasa yang sederhana, hal ini dilakukan dengan tujuan agar khalayak mampu memilih atau menyaring isi pesan yang disampaikan oleh media. Khalayak dapat membedakan mana yang dianggap penting atau baikdan manayang dianggap buruksehingga masyarakat akan lebih meningkat kompetensi literasi digitalnya. Kompetensi yang diharapkan akan bisa ditingkatkan adalah kompetensi untuk mengakses, menyeleksi, memahami, menganalisis, memverifikasi, mengevaluasi, mendistribusikan, memproduksi, berpartisipasi, dan berkolaborasi. Pada tahap mengevaluasi inilah khalayak diharapkan sudah memiliki kemampuan mengakses, cerdas, aktif, dan mampu lebih kritis dalam mengonsumsi media. Pentingnya peran orang tua dalam literasi digital juga ditunjukkan dalam penelitian sebelumnya, yaitu penelitian mengenai gerakan literasi digital di Indonesia yang dilakukan oleh Jaringan Pegiat Literasi Digital (Japelidi) pada tahun 2017. Dalam penelitian ini, orang tua (12.3\%) adalah salah satu kelompok sasaran kegiatan literasi digital selain pelajar $(29,55 \%)$, mahasiswa $(18,5 \%)$, masyarakat umum $(15,22 \%)$, guru dan dosen $(10,14 \%)$, komunitas $(7,16 \%)$, lainnya (ormas, LSM, media, pemerintah) sebanyak (6,86\%), dan peneliti yang hanya 0,29\% (Kurnia, 2017).

\section{METODE}

Pelaksanaan program pengabdian ini di Kampung KB Kelurahan Gedawang, Kota Semarang dengan melibatkan kelompok Ibu-Ibu PKK. Metode pelaksanaan kegiatan pengabdian ini dilakukan sebagai berikut:

Pertama, menghubungi mitra pengabdian masyarakat untuk menjelaskan maksud dan tujuan serta mendisuksikan persoalan yang dihadapi di era digital ini untuk menentukan metode atau program penyuluhan yang tepat. Dalam hal ini metode Focus Group Discussion (FGD) agar lebih terarah dan tepat sasaran.

Kedua, penyuluhan dilakukan melalui FGD dengan sarana dan prasarana yang digunakan meliputi ruangan disalah satu rumah warga, seperangkat sound system, proyektor, layer proyektor, papan tulis, dan meja yang disiapkan oleh kedua belah pihak baik warga setempat maupun tim pengabdian. Dalam FGD ini diberikan beberapa informasi dan isu-isu yang dihadapi di era digital dalam kehidupan rumah tangga. FGD dimulai dengan pemaparan materi ilmiah untuk meningkatkan pemahaman masyarakat secara ilmiah, selanjutnya dilakukan tanya jawab.

Ketiga, simulasi dalam menangkal informasi palsu (hoaks). Penerapan metode simulasi ini diharapkan dapat meningkatkan pengetahuan dan mengatasi permasalahan yang berkaitan dengan informasi palsu. Setelah menyelesaikan kegiatan pengabdian maka dilakukan monitoring dan evaluasi (Monev) untuk mengetahui tingkat pemahaman peserta.

\section{HASIL DAN PEMBAHASAN}

Kehidupan masyarakat telah berubah sejak adanya media digital, penggunaannya bukan hanya mereka yang berada di kalangan atas saja, melainkan masyarakat lapisan bawah. Kemudahan dalam mendapatkan informasi, peluang usaha, hiburan, dan pendidikan telah membawa media sosial erat dengan kehidupan sehari-hari didalam keluarga. Terlepas dari perdebatan definisi yang ada, kehadiran media baru dalam masyarakat modern memberikan ruang yang lebih luas yang memungkinkan proses produksi dan distribusi informasi serta volume informasi tidak lagi dibatasi oleh ruang dan waktu (Kurnia, 2017).

Tahap pertama yang dilakukan dalam pendampingan ini tim menghubungi mitra untuk menentukan jadwal kunjungan. Setelah mendapatkan informasi jadwal berkunjung, kemudian pada tanggal 20 Agustus 2019 tim bersilaturahmi kepada ketua RW Bapak Kuslani dan perwakilan kelompok masyarakat pelaku dan penggiat kampung KB di Gedawang. Diadakan dialog tentang kondisi dan permasalahan serta harapan kelompok masyarakat. Tim menawarkan solusi untuk dilakukan pendampingan. Tim menginformasikan tentang pentingnya pelatihan dan pendampingan literasi digital dengan melakukan Focus Group Discussion (FGD) dan simulasi.

Tim dan ketua RW atau ketua kampung KB desa serta anggota kelompok membuat kesepakatan jadwal pertemuan dan anggota menyatakan komitmen untuk selalu hadir dalam pertemuan-pertemuan yang sudah disepakati. Pada kesempatan tersebut disepakati jadwal 
untuk dilakukan dua kali pertemuan yakni pada tanggal 15 September 2019 dan 13 Oktober 2019. Kemudian tim terjun ke masyarakat untuk mendata sekali lagi detail permasalahan mitra kepada anggota kelompok.

Tahap kedua, pada pertemuan pertama tim mengadakan penyuluhan dan pendampingan literacy digital melalui FGD pada tanggal 15 September 2019, bertempat di salah satu rumah warga kelurahan Gedawang, Kecamatan Banyumanik, Kota Semarang pukul 19.00-21.00 WIB. Kegiatan tersebut dihadiri oleh Ketua RW atau Ketua Kampung KB dan 40 anggota masyarakat Kampung KB yang dalam hal ini adalah Ibu-Ibu PKK. Latar belakang masyarakat peserta diskusi yang beranekaragam tersebut merupakan salah satu hal positif karena proses transfer informasi dan pengetahuan menjadi lebih optimal.

FGD dimulai dengan pemaparan materi. Dalam pemaparan tersebut pemateri menyampaikan bahwa Literasi digital memiliki tiga elemen penting yaitu kompetensi atau kecakapan yang harus dimiliki individu ketika mengakses media digital. Elemen kedua adalah lokus personal, individu yang berinteraksi dengan individu yang lain. Pada titik ini, konsekuensi sosial dari literasi digital ini menjadi sangat penting karena individu memahami apa yang diperlukan dalam mengakses media digital, dan yang ketiga adalah struktur pengetahuan.

Sifat internet yang dua arah juga memungkinkan seorang pengguna menjadi seorang produser sekaligus. Pengguna tidak hanya pasif menerima pesan namun juga secara aktif dapat melakukan produksi pesan. Sifat internet yang juga personal memfasilitasi pengguna dalam menyeleksi pesan yang diinginkannya. Sifat internet yang demikian memberikan kontribusi pada bagaimana pengguna mengaplikasikannya. Berbagai isu mengenai penggunaan internet dalam keluarga dan penggunaannya oleh anak-anak semakin mendapatkan perhatian.

Dikutip dari makassar.tribunnews.com, pada Januari 2019, Global Digital Report 2019 menyebutkan bahwa jumlah penduduk Indonesia telah mencapai 268,2 juta jiwa dengan penetrasi internet mencapai 150 juta atau (56\%). Dengan rata-rata durasi yang digunakan, diantaranya: akses internet (8 jam 36 menit), sosial media ( 3 jam 26 menit), televisi ( 2 jam 52 menit), dan streaming musik (1 jam 22 menit). Dengan fakta tersebut maka dari 24 jam waktu manusia sebagian besarnya digunakan untuk beraktivitas di dunia internet, sebuah ruang interaksi tanpa sekat. Yang menjadi masalah disini adalah bahwa sebagian besar dari 56\% pengguna internet di Indonesia tidak menyadari bahaya yang mengintip dari setiap aktivitasnya di ruang maya ini.

Fakta bahwa dari setiap informasi yang dibagikan oleh para pengguna internet ketika berinteraksi berpotensi untuk disalahgunakan oleh pihak-pihak yang tidak bertanggung jawab tanpa persetujuan pemilik data atau subyek data (https://makassar.tribunnews. com/2019/12/16/minta-pemerintah-dan-dprri-bahas-ruu-perlindungan-data-pribadi-iniupaya-masyarakat-sipil).

Kajian mengenai peran orang tua dalam mengelola internet dalam keluarga juga merupakan kajian yang cukup populer. Beberapa peneliti bahkan menunjukkan aturan orang tua terhadap anak dalam penggunaan internet dan kontrol terhadapnya, seperti penggunaan piranti filter dan sebagainya (Hughes \& Hans, 2004). Walaupun demikian, dalam kehidupan seharihari masih terbatas orang tua yang menaruh perhatian pada penggunaan internet oleh anak di rumah dibandingkan dengan perhatian pada persoalan lain seperti pendidikan, bahaya narkoba, dan kejahatan (Livingstone, 2002:124).

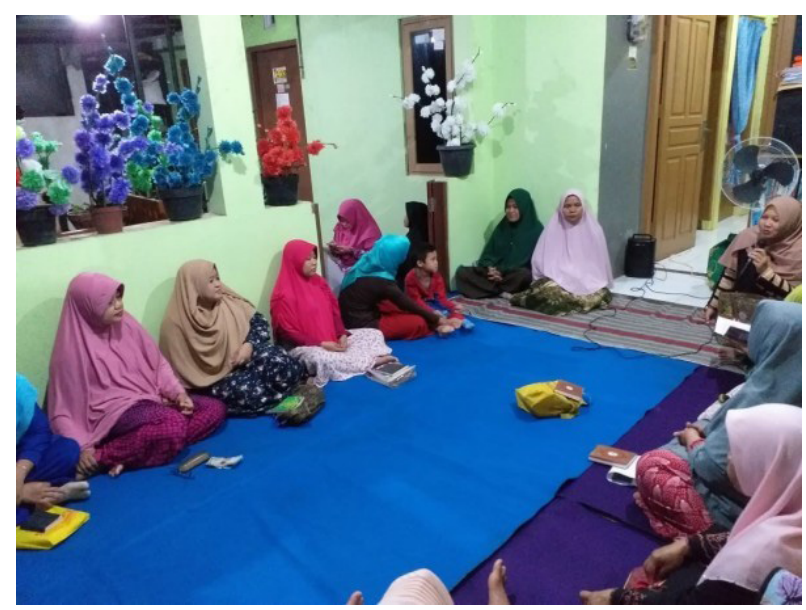

Gambar 1. Pemateri Menyampaikan Penyuluhan 
Dapat dikatakan di sini, dalam masyarakat modern internet justru merupakan media yang kurang mendapatkan pengawasan dari orang tua karena minimnya panduan dan kurangnya pengetahuan orang tua terhadap internet Leung \& Lee (dalam Kurnia, 2017:9). Teknologi digital terus merangsek kehidupan keluarga saat ini tanpa terbendung. Baik orang tua maupun anak-anak menjadi pengguna media digital dalam berbagai bentuk, seperti komputer, telepon pintar, piranti permainan/gim, maupun internet.

Penggunaan media digital di rumah ternyata tidak serta merta meningkatkan kualitas kehidupan berkeluarga. Tak jarang anggota keluarga justru terpisahkan karena lebih tertarik menghabiskan waktu dengan perangkat digital mereka daripada berinteraksi bersama. Lebih parah, orang tua dan anak bisa mengalami masalah kecanduan gawai (gadget). Maka orang tua perlu mengembangkan cara baru mendidik anak di era digital.

Selama betahun-tahun kita percaya anakanak generasi $\mathrm{Y}$ adalah digital native, kalangan yang lahir bersamaan dengan teknologi digital sehingga otomatis mampu menguasainya. Ternyata, digital native adalah mitos belaka. Kemahiran generasi ini ditentukan oleh berbagai faktor. Antara lain terpaan teknologi digital, tingkat pendidikan ibu, dan tingkat ekonomi keluarga. Anak-anak yang lahir di keluarga kelas ekonomi dan sosial menengah cenderung lebih mahir, produktif, dan memahami keamanan teknologi digital dibandingkan anak-anak kelas bawah yang hanya diajari gawai untuk permainan dan hiburan. Apalagi bila ibunya tidak pernah mendiskusikan teknologi itu (Livingstone, 2002).

Tahap Ketiga, pelaksanaan simulasi yang dilakukan pada tanggal 13 Oktober 2019 bertempat di rumah salah satu warga Keluarahan Gedawang, Kecamatan Banyumanik, Kota Semarang pukul 19.00-21.00 WIB. Kegiatan tersebut dihadiri oleh peserta yang sama dengan jumlah 38 anggota masayarakat Kampung KB. Penggunaan metode simulasi dimaksud untuk memberikan gambaran keadaan yang sebenarnya. Peserta dalam kegiatan pengabdian ini diberikan pelatihan dan simulasi literasi digital dalam kehidupan ber-rumah tangga. Di mana Keluarga menjadi bagian penting untuk meminimalisir terjadinya penyebaran informasi bohong (hoax), terlebih memberi pemahaman kepada anak-anak agar bisa memilih informasi yang benar.

Langkah-langkah simulasi di antaranya adalah persiapan simulasi, pelaksanaan simulasi, dan penutupan simulasi. Pertama, persiapan simulasi, tim dan peserta membuat kesepakatan untuk menetapkan topik atau masalah serta tujuan yang hendak dicapai oleh simulasi. Kemudian tim memberikan gambaran masalah dalam situasi yang akan disimulasikan, gambaran permasalahan ini adalah mengenai informasi palsu yang berada dalam lingkup keluarga dan peran orang tua di dalamnya. Tim memberikan gambaran masalah dalam situasi yang akan disimulasikan, gambaran permasalahan ini adalah mengenai informasi palsu yang berada dalam lingkup keluarga dan peran orang tua di dalamnya. Tim memberikan kesempatan untuk bertanya khususnya kepada anggota masyarakat yang terlibat dalam pemeran simulasi. Anggota masyarakat yang terlibat mulai memainkan peran sesuai dengan topik yang telah ditentukan. Ketiga penutupan simulasi. Tim dan peserta kembali melakukan diskusi tentang jalannya simulasi maupun materi cerita yang disampaikan. Dalam kesempatan ini peserta mulai kritis terhadap permasalahan yang disimulasikan.

Anak-anak sebagaimana generasi sebelumnya membutuhkan bimbingan dan arahan dari orang tua untuk menggunakan media digital dengan bijaksana. Maka orang tua perlu memahami nilai utama dunia digital yang menyetir kehidupan kita saat ini. Ada tiga nilai penting: kreativitas, kolaborasi, dan berpikir kritis.

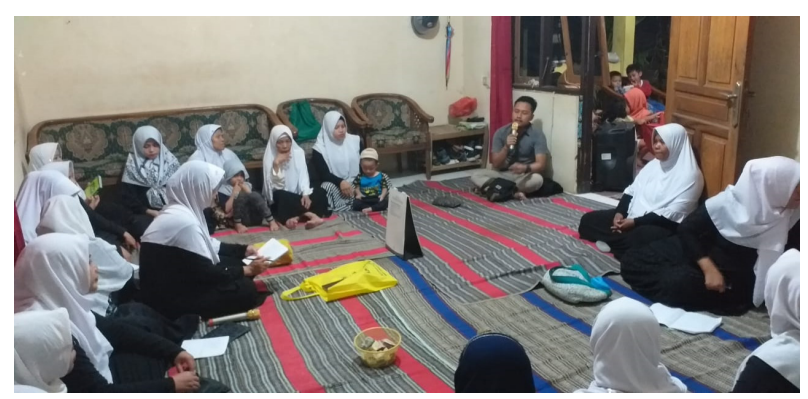

Gambar 2. Tim Melakukan Simulasi 
Kreativitas di era digital dapat dikembangkan melalui berbagai pengalaman menggunakan media digital. Pengalaman itu meliputi keterampilan mengolah kata, suara, angka, gambar, dan sebagainya. Pengalaman juga didapat melalui pengenalan berbagai platform media digital seperti website, media sosial, piranti lunak, dan aplikasi layanan. Kemampuan dan kreativitas untuk menjelajahi berbagai sudut dan potensi media digital sangat penting dalam menunjang kehidupan generasi di masa depan.

Kolaborasi adalah nilai yang dibawa oleh media digital karena cakupannya yang nyaris tak berbatas, dari sisi isi maupun penggunaannya. Media digital memungkinkan kita untuk berkomunikasi dan berinteraksi dengan banyak orang dengan mudah. Agar tak tersesat, anak-anak perlu belajar berinteraksi dan bekerja sama dengan orang dari beragam latar belakang budaya dan keterampilan. Oleh karena itu keterampilan berkomunikasi, bernegosiasi, menghargai pendapat orang lain, hingga membagi tugas harus dikuasai oleh anak. Orang tua perlu merancang kegiatan di luar sekolah yang tidak befokus pada kompetisi tapi kolaborasi untuk mengembangkan kemampuan ini.

Kritis dalam berpikir penting diajarkan pada anak-anak. Mereka menghadapi media digital yang memuat berbagai konten dan pesan dari seluruh penjuru dunia dengan nilai-nilai yang berbeda. Maka setiap keluarga perlu menanamkan nilai-nilai kehidupan yang diafirmasi setiap keluarga pada anak-anaknya. Jika hal itu berhasil dilakukan orang tua, maka anak-anak akan mengembangkan pola pikir dan sikap kritis dalam bermedia dan mampu memanfaatkan fasilitas media yang serba canggih untuk kegiatan-kegiatan positif.

Kemampuan untuk menguasai ketiga nilai tersebut dan mengkombinasikannya akan membuat pengguna media digital tak hanya menjadi pengguna digital yang pasif, melainkan pengguna media digital yang aktif dan mampu menggali potensi tersembunyi dari media ini. Anak-anak yang masih dalam masa perkembangan akan memiliki waktu lebih banyak untuk memelajarinnya dan mengembangkan keterampilan ini sehingga mereka memiliki peluang lebih besar untuk bisa mengoptimalkan penggunaan media digital untuk hal yang bermanfaat (Herlina dkk., 2018).

Selain itu, pemateri juga menyampaikan pentingnya etika informasi. Etika informasi adalah Kesadaran untuk mengevaluasi berbagai isu yang terkait dengan penyebaran data elektronik. Mencakup di dalamnya bagaimana menyaring hoax, memilah informasi, dan bagaimana menyampaikan informasi dengan baik. Pemilahan informasi juga dapat dilakukan sebagai berikut:

1. Cek dulu apakah berita itu benar dengan mencari sumber aslinya.

2. Hanya percaya sumber informasi yang kompeten, misalnya media yang sudah diakui kualitasnya.

3. Apakah informasi itu berisi sensasi atau provokasi negatif? Jika ya, sebaiknya jangan disebar.

4. Pastikan informasi itu tidak mengandung ujaran kebencian, hoaks, fitnah.

Derasnya arus informasi membuat kita kerap sulit memilah mana informasi yang benar, setengah benar, atau salah. Kita juga kesulitan memahami bagaimana menyebarkan informasi yang benar. Di sinilah dibutuhkan kesadaran etika informasi, di mana kita diajak untuk mengerti bagaimana menyampaikan atau menerima informasi online secara baik dan benar. (Acep Syaripudin dkk., 2018)

Terlebih lagi, dengan beredarnya hoaks dan fitnah di media sosial mendorong MUI mengeluarkan Fatwa MUI No 24 tahun 2017. Fatwa itu membahas tentang Hukum dan Pedoman Bermuamalah melalui Media Sosial. Ketua umum MUI Ma'ruf Amin mengatakan, fatwa tersebut dibuat berdasarkan kekhawatiran akan maraknya ujaran kebencian dan permusuhan melalui media sosial. Dalam fatwa MUI tersebut tercantum beberapa hal yang diharamkan bagi umat Islam dalam penggunaan media sosial. Setiap muslim yang bermuamalah melalui media sosial diharamkan untuk:

1. Melakukan ghibah, fitnah, namimah, dan penyebaran permusuhan.

2. Melakukan bullying, ujaran kebencian, dan permusuhan atas dasar SARA. 
3. Menyebarkan hoaks serta informasi bohong, meskipun dengan tujuan baik, seperti info tentang kematian orang yang masih hidup.

4. Menyebarkan materi pornografi, kemaksiatan, dan segala hal yang terlarang secara syar'i.

5. Menyebarkan konten yang benar tapi tidak seusai tempat dan atau waktunya.

Para peserta kegiatan ini memiliki komitmen untuk menjadi pelopor anti hoax dalam era disrupsi informasi seperti saat ini. Serta memanfaatkan media sosial dengan tujuan yang lebih bermanfaat seperti bisnis online atau membagikan informasi yang bermanfaat lainnya guna mendukung gerakan Keluarga Berencana.

Luaran dari kegiatan pengabdian ini selain dokumentasi kegiatan, juga publikasi di media cetak dan online, diantaranya di koran wawasan, suarabaru.id, rri.co.id. Di samping itu juga pembuatan artikel ilmiah yang dimuat di jurnal pengabdian masyarakat.

\section{SIMPULAN}

Berdasarkan kegiatan yang telah dilakukan dapat disimpulkan bahwa peserta kegiatan pengabdian masyarakat memperlihatkan antusiasme yang baik. Para peserta juga menyadari bahwa informasi bohong (hoax) dapat membuat kegaduhan dan situasi yang tidak kondusif. Mereka juga menyadari betapa pentingnya peran orang tua dalam mendampingi anak-anak dalam pemanfaatan media digital. Di sinilah para orang tua perlu memahami nilai utama dunia digital yang menyetir kehidupan kita saat ini. Ada tiga nilai penting: kreativitas, kolaborasi, dan berpikir kritis. Gambaran Ilmu Pengetahuan dan Teknologi yang ditransfer dari kegiatan pengabdian masyarakat ini dapat disimpulkan adalah meningkatnya pengetahuan masyarakat di Kampung KB RW 2 Kelurahan Gedawang, Semarang dengan beberapa kegiatan yang dilakukan seperti penyuluhan dan diskusi. Pelaksana juga memberikan informasi atau menyebarkan pesan secara langsung kepada ibu-ibu PKK dan remaja di Kampung KB RW2 Kelurahan Gedawang, Semarang dilakukan supaya mereka mengetahui, mau dan mampu merubah perilaku dengan bertambahnya pengetahuan yang diberikan.

Pada aspek peningkatan keterampilan dengan pelatihan, dalam alam PKM ini, keahlian yang diberikan mampu meningkatkan kompetensi untuk mengakses, menyeleksi, memahami, menganalisis, memverifikasi, dan mengevaluasi, sedangkan untuk kompetensi mendistribusikan, memproduksi, berpartisipasi, dan berkolaborasi menjadi tahapan kompetensi yang bisa dikembangkan lagi dalam kegiatan selanjutnya. Keterampilan yang dilatih adalah melalui simulasi yang diberikan dan contohcontoh informasi yang masuk dalam kategori mis informasi, disinformasi dan menunjukkan mana yang masuk dalam kategori hoaks dan bukan.

\section{PERSANTUNAN}

Program pengabdian masayarakat ini bisa terlaksana berkat dukungan dari Ir. Prabowo Setiyawan, Ph.D. (Rektor Universitas Islam Sultan Agung UNISSULA Semarang, Dr. Heru Sulistyo, M.Si. (Kepala LPPM Universitas Islam Sultan Agung Semarang), dan masyarakat kampung KB Kelurahan Gedawang, Kecamatan Banyumanik, Kota Semarang yang memiliki kontribusi besar terhadap pengabdian ini.

\section{REFERENSI}

Acep S, dkk. (2018). Kerangka Literasi Digital Indonesia. Literasidigital.id.

Endah, T., Dimas, A., \& Akmal, N. (2017). Kajian Dampak Penggunaan Media Sosial bagi Anak dan Remaja.

Herlina, D., Setiawan, B. G. J. A., \& Adikara, G. J. (2018). Digital Parenting: Mendidik Anak di Era Digital. Bantul: Samudra Biru.

Hughes Jr, R., \& Hans, J. (2004). Understanding The Effects of The Internet on Family Life. London: Sage. 
Kurnia, N., \& Astuti, S. I. (2017). Peta Gerakan Literasi Digital di Indonesia: Studi Tentang Pelaku, Ragam Kegiatan, Kelompok Sasaran dan Mitra yang Dilakukan oleh JAPELIDI. Informasi, 47(2), 149-166.

Lievrouw, L. A., \& Livingstone, S. (Eds.). (2002). Handbook of New Media: Social Shaping and Consequences of ICTs. London: Sage.

Novianti, D., \& Fatonah, S. (2018). Literasi Media Digital di Lingkungan Ibu-Ibu Rumah Tangga di Yogyakarta. Jurnal Ilmu Komunikasi, 16 (1).

Potter, W. James.(2004). Theory of Media Literacy: A Cognitive Approach. London: Sage Publication.

Fatwa MUI No 24 tahun 2017 Tentang Hukum dan Pedoman Bermuamalah melalui Media Sosial.

https://makassar.tribunnews.com/2019/12/16/minta-pemerintah-dan-dpr-ri-bahas-ruuperlindungan-data-pribadi-ini-upaya-masyarakat-sipil?page=all

https://techno.okezone.com/read/2018/09/17/56/1951473/riset-ungkap-ibu-ibu-semakin-gencarbermain-internet 